\title{
Effects of Teachers' Participation in Management of Physical and Material Resources on Their Motivation, Kenya
}

\author{
Petronilla M. Kingi \\ Jeremiah M. Kalai \\ University of Nairobi, Kenya
}

Doi: 10.19044/esj.2018.v14n10p284 URL:http://dx.doi.org/10.19044/esj.2018.v14n10p284

\section{Abstract}

Motivation is one of the many factors that contribute to employee performance. Teachers' motivation in public secondary schools has been highlighted as one of the factors that contribute to employee performance (Matoke, Okibo \& Nyamongo, 2015). There is however a dearth of literature on the effects of teachers' level of participation in management of physical and material resources on their motivation. The purpose of this study was to investigate the effects of teachers' levels of participation in management of physical and material resources on teachers' motivation in public secondary schools in Kiambu, Machakos and Kajiado Counties, Kenay. The study sought to establish whether there was a significant relationship between the teachers' level of participation in management of physical and material resources on teachers' motivation in secondary schools. The study used Kurt Lewin change management model (1951) and Herzeberg Motivation Hygiene Theory (1959). Correlation design was adopted with a sample size of 58 principal and 345 subject teachers. Data was collected using questionnaires for the teachers and principals and self-administered observation guide. Stratified random sampling technique was used to get the sample size of the respondents. Validity was established through expert consultation and reliability determined using cronbach alpha. Means were computed to compare the teachers' and principals' opinions on the teachers' level of participation in management of physical and material resources. Mean of below 2.00 was considered low level, mean between 2 to 3.5 was moderate whereas as mean above 3.5 was regarded high level. Independent t-test was used to establish whether there was a statistical mean difference between the teachers and school principals' opinion on the teachers' level of teachers' participation in management of physical material resources. Simple regression analysis was carried out in order to establish the effect of teachers' participation in the management of physical and material resources on their motivation. The study 
established that teachers were moderately involved in management of physical and material resources. The independent sample t-test results shows that there was a significant difference in the mean difference between the means of principals' and teachers' views on teachers' participation in management of physical and material resources $\mathrm{t}(377)=-6.073, \mathrm{p}=0.00$. The study revealed a statistical significant relationship between teachers' level of participation in the management of physical facilities and their motivation $(\beta=.399, p$-value $<$ $.01)$.There is need to embrace participative structures that encourage teachers' participation in management of physical facilities and material resources. Through such ventures the teachers will highly be motivated to work and consequently improving the quality of education in Kenya.

Keywords: Teachers' participation, management, physical facilities, material resources, commitment, and motivation, secondary schools

\section{Introduction}

Over the last decade, research shows that the major problem in provision of education has always been attributed to lack of physical and learning resources in school environment. Many schools in developing and developed countries indicate lack of adequate physical and material resources which has detrimental effects on motivation (Olatunji, 2013; Isaiah 2013; Akinfolarin 2015). Vanbaren (2010) defines teacher motivation as a process of encouraging and inspiring teachers to perform their duties effectively. Teacher's participation in management of physical facilities and material resources is a critical aspect because knowledge, skills and values are learned at school. According to Freeman, Greene, Dreibelbis, Saboori Muga, Brumback, Rheingans (2011) school facilities and materials comprises of sanitation, hygiene and water reservoirs. They argue that students and teachers in developing countries spend most of their time absent from schools due to diseases contracted within the school environment. The evidence of inadequate facilities suggests the need for greater infrastructural investment in most institutions. Leithwood and Jantzi (2006) carried out a study on teacher working conditions as evidence for change. The study established that teachers' motivation is associated with positive attitudes, optimistic views, and enthusiasm whereas low motivation is associated with cynicism and feelings of despair. Further, he found out that behaviour associated with low morale included less effective teaching performance, absenteeism, turnover and resistance to change.

Duran (2008) examined the extent to which the availability of adequate infrastructure affected the achievement of educational goals in Zimbabwe. The study used qualitative design comprising of 20students and 32 teachers. The study findings indicated that teachers did not participate in provision of 
school infrastructure. Further, the study revealed that equipped school were more functional and presented better learning opportunities. It is however not known how teachers participation in management of physical and material resources affects teacher's motivation thus this study sought to establish the effect of teacher in management of physical and material resources in Kiambu, Machakos and kajiado Counties. The study recommended school managers and policy makers should take note of the positive impact that a functional, clean and attractive school building can make on education. Earthman (2004) argued that building features such as ventilation, lighting, acoustical control, design classification and overall impression have effect on teachers' motivation. According to Dorman (2008), physical and materials resources comprises of textbooks, laboratories, chemicals, tools and equipment, teaching aids, stores and offices. He reported that factors affecting teachers' motivation included the nature policies on the use of the physical and material resources and working conditions. Sergiovanni (2009) stated that school managers needed to recognize the importance of teachers' participation in management of school facilities and material resources. He asserted that effective schools strived to motivate teachers by providing adequate learning resources. A study by Bush, Joubert, Kiggunduand, Rooyen (2010) examined the significance of participative management in enhancing instructional and learner outcome in South Africa. The study used case study design. The study revealed that most of the schools lacked teaching-learning materials and teachers were poorly motivated.

Devos, Tuytens, \& Hulpia (2014), conducted a study on the relationship between principals' leadership styles and teachers organizational commitment. Data were collected from 1495 teachers in secondary schools. The study used structural equitation model. The findings indicate the principals' leadership style and teachers' commitment was as a result of distributed leadership (deputy principal, teacher, participative decision making, and collaboration). The path model revealed satisfactory model fit results $\chi^{2}=231.41(\mathrm{df}=27 ; \mathrm{p}<.001) \mathrm{TLI}=.925, \mathrm{AGFI}=.938, \mathrm{RMSEA}=.071$. The principals' leadership style explains $20 \%$ of the variance in teacher leadership; $36 \%$ of the variance in participative decision making; $44 \%$ of variance in teachers' commitment was attributed to distributive leadership and principals' leadership. However, the direct influence of the principal leadership on teachers' commitment was rather weak. This study focused on relationship between principles' leadership styles and teachers' organizational commitment while the current study focused on the effect of teachers' level of teachers' participation on their motivation.

Lewin (2008) states that teachers' participation in the management of physical and material resources comprised of maintaining, procuring equipment and learning materials. Slaouti and Barton (2007) argued that lack 
of ICT facilities and mentors, poor time management and lack of opportunities for apprenticeship had negative effects on motivation. The focus of the current study is the level of teachers' participation in management of physical and material resources using regression analysis.

Korkmaz, İhsan, Yildiz and Fikret (2011) undertook a study to investigate the effect of 12-weeks recreational activities on university students' self-esteem. The sample consisted of 40 students from Duzce University. Experimental group consisted of 20 students while group comprised of 20 students. Descriptive statistics, independent sample t-test, paired sample t-test and Pearson's correlation analysis were used to analyze the data. Level of significance was 0.05. Recreational activities consisted of football, volleyball, swimming facilities among other facilities. Post-test applications were made after 12 weeks. There was no significant difference between pre-test and posttest for control group ( $p>0,05)$, pre-test and post test scores of experimental group significantly differed $(\mathrm{p}=0.05)$, a significant difference appeared between post-test self-esteem points of experimental group and control group $(\mathrm{p}=0.05)$. As a result, recreational facilities and activities positively affected self-esteem of university students. The study by Korkmaz, İhsan, Y1ldiz, Fikret focused on effect of 12-weeks recreational activities on university students' self-esteem yet this study attempted to establish the effect of teachers' level of participation in management of physical and material resources on teachers' motivation.

Abdul and Isaac (2016) carried out a study the state of academic facilities and its influence on teachers' job stress in Tamale polytechnic. The study adopted a case study approach in a tertiary institution in Ghana. Accidental sampling technique was used to select the study size. A questionnaire was used for data collection. Cronbach's Alpha and KMO was used to test sample reliability which yielded coefficients ranging from 0.734 to 0.755 . Data were analyzed using inferential statistics (Pearson Product Moment Correlation and multiple regressions. Results revealed a significant statistical relationship between the status of facilities and teachers' motivation. It was concluded that inadequate academic productivity exerted pressure on teachers. The study focused on the effect of recreational activities on teachers' motivation. However the current study focused on the teachers' level of participation in management of physical facilities on motivation.

Ali, Naeimeh, Javad and Hatam (2015) examined the relationships between teachers' perceptions of organizational commitment and school health in Turkish primary schools. The sample comprised of 323 randomly selected teachers from 20 primary schools. Results indicated that teacher compliance and commitment was negatively related to both identification and internalization. School health facilities, institutional integrity, principal professional leadership and morale negatively predicted teacher commitment 
based on compliance. Professional leadership was the only school health dimension that was significant in predicting identification commitment. Moreover, school health, academic emphasis and resource support were not significant predictors of teachers' commitment. The study examined the relationships between teachers' perceptions of organizational commitment and school health while the current study focused on the level of teachers' participation in management of physical and material resources on their motivation.

Jasper and Le, Bartram (2012) carried out a study on water and sanitation in schools in relation to health and educational outcomes. The goal was to establish the impacts of water and sanitation the school environment. Water shortage had negative effects of attendance, physical, social and psychological aspects. The study also revealed higher rates of absenteeism from schools during menses due to poor sanitation facilities. Furthermore, there was decrease in diarrheal and gastrointestinal diseases with increased access to adequate sanitation facilities. Easy access to safe drinking water and hygienic toilets that provided privacy to users had positive impact on students' and teachers' health which influenced motivation. The study by Jasper, and Le Bartram focused on provision of water and sanitation in relation to health and educational outcome however the current study was on the effects of participation on teachers' motivation.

A study by Garipagaoglu (2013) revealed that lack of physical facilities and poor salaries affected had negative effects on teachers' commitment and motivation. According to Ayeni and Adelabu (2012) lack of teachers' participation in management of facilities (furniture, ventilation, incinerators, urinals and audio-visuals) resulted into low morale among teachers. They also stated that teachers' participation led to creativity and commitment while absence of such facilities led to poor performance of duties (Osei, 2006). These authors had focused more on teachers' work performance and therefore a gap existed in relation to effects of teachers' participation in management of physical and material resources on their motivation.

Gouri, Pravat and Soumen (2012) carried out a study on assessment of school infrastructure at Primary and Upper Primary Level: A Geospatial Analysis. The study focused on infrastructure accessibility, type and conditions of the classrooms. Moran's I statistics was used to estimate the spatial distribution of infrastructure. The facilities comprised of toilets, drinking water, library, electricity, ramps, perimeter wall, playground, and kitchen and computer facility. The facilities were assigned weights based on Saaty's analytical hierarchy. The thematic areas were integrated in GIS software based on multi-criteria approach in Oder to provide educational development infrastructure index. Mean values were categorized into eight groups whereby: 1 to 1.5 was regarded poor; 2 to 3.5 moderate; 4 to 5.5 good; 
6 to 7.5 very good; 8 to 9 excellent. Four different zones were delineated very good, good, moderate and poor. The study concluded that Geo-informatics technology was significant and useful in identification of infrastructure development. The study did not establish the effects of the teachers' level of participation in management of physical facilities and material resources which is the purpose of this study.

In Ghana, Salifu (2014) carried out a study on barriers to teacher motivation for professional practice in the education sector. The study used the qualitative approach method. The findings revealed frustrations and stress in the teaching profession as a result of poor working conditions. Further, he argued that the size of the classes, working hours, management styles and the school location were some of the factors which affected teachers' motivation. The study did not look at participation in relation to motivation which is the focus of this study. In Zambia, Wadesango (2012) reported that teachers' participation in management of physical facilities resulted into low morale and stressful school governance. He observed that teachers' participation in management of physical facilities improved the working conditions. However, Wadesango failed to indicate the level of participation and the nature of the relationship.

Ayeni and Afolabi (2012) carried out a study on teachers' instructional task performance and quality assurance of students' learning outcomes in Nigerian secondary schools. The findings indicated that teachers' instructional work entailed delivery of lessons, evaluation of learning outcome, classroom management, and feedback. Apparently, this study was conducted in a secondary school setting and captured performance of teachers' instructional work. However the study did not focused on the level of teachers' participation in management of physical and material resources on their motivation.

Ayele (2014) carried out a study on Teachers' job satisfaction and commitment in general secondary schools of Hadiya Zone in Nigerian secondary schools. The study focused on the internal and external factors of teachers' job satisfaction and level of teachers' commitments, a total of 159 respondents comprising of 119 , eight (8) principals, 16 deputy-principals, 8 supervisors and eight (8) education office expertise. Questionnaire and interview were the main instruments of data collection. The analysis of the quantitative data was carried out by using mean, standard deviation and Pearson product correlation coefficient. The findings indicate a significant and positive relationship between teachers' job satisfaction and commitment $(\mathrm{r}=$ $.77, \mathrm{~N}=105),(\mathrm{r}=.71, \mathrm{~N}=30)$. Higher levels of teachers' job satisfaction were associated with higher levels commitment. The study recommended provision of adequate facilities, equipment and material such as staff housed, waters, electricity, transport, working conditions and refreshments. Moreover, 
the study did not show the effects of the relation which is the purpose of this study.

Further, Kimutai and Kosgei (2012); Ayeni and Afolabi (2012) argued that quality of teachers' work had a significant impact on pupils' academic achievement. The two authors focused on teachers' work performance and therefore the existing gap was to establish effect of teachers' participation in management of physical and material resources on their motivation. Mwangi (2013) argues that teachers lack enthusiasm and were unable to teach effectively to achieve the instructional objectives. Ayele (2014) reported that teachers had negative attitudes toward towards the teaching profession due to poor performance of students in national examinations. Apparently a gap existed to determine the effect teachers' participation in management of physical and material resources on their motivation which was not focused in the study.

King'oina, Kadenyi and Ngaruiya (2015) carried out a study to investigate the effect of teachers' morale on standard eight pupils' academic achievement in public primary schools in Marani Sub-County, Kenya. The study utilized ex-post facto design. Simple random sampling technique was used to select a sample of sample size was 100 teachers. Questionnaire was used in data collection. Data was analyzed using frequencies, percentages and means and Pearson coefficient correlation. All null hypotheses tested at 0.05 alpha level were rejected and led to affirmation that there was a significant relationship between teachers' morale and pupils' academic achievement. Based on the results, the study recommended school managers to teachers' participation in internal quality assurance programmes. Educational stakeholders were encouraged to supported and motivate teachers in order to improve academic performance in schools. The study investigate the effect of teachers' morale on standard eight pupils' academic achievement leaving a gap on effects of teachers participation on their motivation.

Ireri (2015) carried out a study on the influence of motivation on employee performance in Non-governmental Institutions in Kenya. The study focused on the influence of compensation, promotion, recognition and supervision on employee performance among the employees of Kenya Tenri Society. The study adopted a descriptive research design. Data was collected using a questionnaire. The data was analyzed using frequencies, means and Pearson's co-efficient correlation. The findings indicated a significant statistical difference between compensation, promotion, recognition and supervision on employee performance in the four aspects. The study recommended the NGOs to develop and implement payment clear promotion structures, career advancement policy, communication channels and to enhance employee recognition with financial rewards that attract competent employees. It was however not known how teachers' participation in 
management of physical and material resources affected teachers' motivation which is the purpose of this study.

Momanyi (2015) carried out a study on factors affecting teacher motivation in public secondary schools in Marani sub county, Kisii County. The study focused on the effect of job satisfaction, reward system, training and development, work situational factors on teacher motivation. Descriptive research design was used for the study. Random sampling technique was used to select teachers while purposive sampling technique was used to select the principals. The sample size consisted of 126 respondents constituting 112 teachers and 14 principals. Questionnaires were used to collect data from teachers while interview schedules were used to collect data from principals. Data was analyzed using means, standard deviation, frequencies and percentages. Content analysis was used to analyze qualitative data from the interview with the principals. The findings indicate a close association between of job satisfaction, reward system, training and development and work situational factors had effects of teachers' motivation. However the study used descriptive statistics and did not establish the effect of participation and motivation which is the purpose of the current study uing regression analysis.

Matoke, Okibo, and Nyamongo (2015) carried out a study on determinants of teacher motivation in public secondary schools in Masaba South Sub-County. He used regression analysis to establish the effect of working conditions, work-load and teaching resources on motivation. The study established that physical and material resources had a significant ( $\mathrm{p}$ value of .041) effect on teacher motivation. The standardized beta value of .764 indicated that an increase in participation in management of physical and material resources by 1 unit increased teachers' motivation. The study was carried out inMasaba Sub-County while the current study was done in Kiambu, Machakos and Kajiado Counties,Kenya. In addition, Juma (2011) revealed that teachers' participation in management of change relating to the provision of classrooms, laboratories, libraries, playing fields and textbooks had positive effects on teachers' motivation. The study did not use inferential statistics.

\section{Statement to the Problem}

In Kenya, the education system places school principals in a position to make all major decisions with little participation of teachers (Republic of Kenya, 2012). This was attested by Mualuko, Mukasa, and Achola (2009); Momanyi (2015); Ireri, (2015)who argued that most school principals often applied non-participatory management styles which hindered teachers' participation in management of physical and material resources hence affecting their morale. Due to this low participation of teachers in management 
of physical and material resources, there was need to carry out a study of this nature in order to establish the effect of teachers' level of participation in management of physical and material resources on teacher's motivation in Kajiado, Kiambu and Machakos counties, Kenya.

1. The study sought to investigate the following objectives:

i) To establish whether a statistical significant mean difference existed between teachers and principals' opinion on the level of teachers' participation in management of physical material resources in public secondary schools.

ii) To determine the effect of teachers' participation in management of physical facilities on levels of teachers' motivation in public secondary schools.

\section{Hypothesis}

$\mathrm{H}_{\mathrm{O} 1}$ : There is no significant relationship between the views of teachers and school principals' on the level of teachers' participation in management of physical material resources in public secondary schools.

$\mathrm{H}_{\mathrm{O} 2}$ : There is no significant relationship between teachers' level of participation in the management of physical facilities and material resources and teachers' motivation in public secondary schools.

\section{Theoretical Framework}

This study was guided by Kurt Lewin change management model (1951) in Stephen, Todd, Kenneth (2015). The change theory is based around a 3-step process (Unfreeze-Change-Freeze) that provides a high-level approach to change. It gives a manager or other change agent a framework to implement a change effort, which is always very sensitive and must be made as seamless as possible. Unfreeze is the diagnostic stage which involves identifying the status quo (problems) and breaking down the existing status quo before building up new ways of operating. It explains why the existing way of doing things cannot continue. Unfreezing is dissatisfaction with the present existing practices. Moving to the new state requires identifying the resisting and the driving forces thus reducing the impediments while enhancing driving forces. Using the analogy of a building one examines the preparedness to change the existing foundations as they might not support addon otherwise the building may risk collapsing. However, the transition does not happen overnight as some may take much longer time to recognize the benefits in order to be highly connected to the organization throughout the transition period. Unfortunately, some are genuinely harmed by change particularly those who benefit strongly from the status quo.

After the change has been put into operation, a process of refreezing (consolidation) becomes necessary. The signs of refreeze include a stable 
organization, consistent job descriptions, new roles, new organization structure, new work methods, constructive amendments. The refreeze stage helps people and the organization to internalize (institutionalize) the changes. With a new sense of stability, they may feel confident and comfortable with the new ways of working. Care should be taken to avoid getting caught up in a transition trap where nothing ever gets done to full capacity. Lewin's (1951) theory has been criticised by several scholars, for instance Dawson, (1994); Dent and Goldberg, (1999); Kanteret al., (1992) argued that the theory is outdated, unfashionable and simplistic. Others argue that Lewin's planned approach is too simplistic, mechanistic and therefore not appropriate for opensystems that are subject to uncertain and turbulent environments (Dawson, 1994; Kanter et al., 1992; Pettigrew, 1990a, 1990b; Wilson, 1992). Despite the criticism, some scholars support the theory by advancing that the theory is more relevant to incremental and isolated change projects which are often the cases for Australian local government (Dawson, (1994). Lewin's contribution to explaining individual and group behaviour during the change process is still relevant in local government context (Burnes, 2004a). The model is also considered to be more appropriate for organisations such as city councils school that are based on traditional top-down, command-and-control style of management, with segmented, small units and slow change timelines. Therefore, Lewin's (1951) models are more appropriate for a top-down, management-driven approaches to change, which is similar to the change management processes employed in city councils (Dawson, 1994; Kanter et al., 1992; Wilson, 1992)

For this study the model is considered appropriate because schools in Kenya are models in a top-down management driven approach. This is as evidenced Basic Education Act, (2012) which indicates that the education system in Kenya places school principals in a position to make all major decisions with little participation of teachers. Mualuko, Mukasa, and Achola (2009) further alludes that most school principals often applied nonparticipatory management styles which hindered teachers' participation in school change management hence affecting their morale. As a result of the head teachers enjoying the monopoly of managing schools, teachers feel demoralized to work. Hence need to apply change management theory which will allow teachers to be involved in the change management of school in areas such as curriculum, physical activities, students and teachers activities, school finance and community relations.

The study was also guided by Herzeberg Motivation Hygiene Theory (Herzeberg, Mouser \& Snyderamn, 1959) in Tan, Teck Hong and Waheed, Amna (2011) which elaborates the factors that cause satisfaction and dissatisfaction among white-collar workers. The theory was later used by among other Schermerhorn (2003); Hunsaker (2005) to elaborate factors that 
lead to motivation and demotivation of the workers. They argued that workers who are not involved in change management of the organization are highly demotivated hence affecting their performance.

According to Herzeberg, Mouser and Snyderamn (1959) factors that produce satisfaction are very different from those leading to dissatisfaction. One concern might produce satisfaction but absence of it would not necessary produce dissatisfaction. Further, they identified extrinsic and extrinsic factors. The extrinsic factors included salary, working conditions while intrinsic factors were the motivators. The hygiene factors (extrinsic factors) included the company policies and administration, supervision, interpersonal relationships, working conditions, salary, status and security. These extrinsic factors caused workers to be dissatisfied while their presence consequently failed to increase job performance. On the other hand motivators make workers to work hard and they are associated with job context or what people actually do at work. They include: achievement; recognition, work-itself, responsibility, and growth or advancement. They are based on a person's ability to achieve and maintain a positive attitude towards their organization and career.

Kurt Lewin deals with change and states that change is a motivator and it is inevitable. This change can either be from within or from outside. Externally, the Teachers Service Commission (TSC), Ministry of Education (MoE), Bill of rights, Kenya vision (2030) exert pressure on the teachers to do things differently in order to accommodate the changing circumstances. From within, there is need to set a social environment where teachers see their personnel needs as being satisfied for motivation purposes. If these personal needs are satisfied it promotes teachers' self-esteem and motivates them to improve the performance of leading to job satisfaction. Change itself is a motivator and therefore the Kurt Lewin model and Herzberg's theory complement each other. The study thus contents that the schools as organizations are concerned with maximizing production and performance while at the same time ensuring that the teachers concerns are catered for in an attempt to achieve the institutional goals. Hence the modern management practices in schools emphasize the need for teacher participation in the management of education change and its effects on teacher motivation.

\section{Methodology}

The study used proportional stratified random sampling techniques to select a sample size 58 school principals and 345 teachers. Data were collected using questionnaires for subject teachers and principals and an observation guide. The study was anchored on Kurt Lewin change management model (1951) and Hertzberg Motivation Theory (Herzeberg, Mouser \& Snyderamn, 1959). Lewin change management model is three-step process (Unfreeze- 
Change-Freeze) which provides change agents a framework to implement change. Herzeberg Motivation Hygiene Theory elaborates the factors that caused satisfaction and dissatisfaction among white-collar workers. Correlation design was adopted with a sample size of 58 principal and 345 subject teachers. Stratified random sampling technique was used to get the sample size of the respondents. Validity was established through expert consultation and reliability determined using cronbach alpha. Data was collected using questionnaires for the teachers and principals and selfadministered observation guide. Teachers were expected to indicate their responses on a five Likerts's scale whereby: 5 represented a greater extent 4 : To some extent 3: Not sure 2: To a little extent and 1: Not at all. According to Bademo and Ferede (2016), the mean value below 2.00 was deemed low level, mean of 2 to 3.5 was moderate whereas mean above 3.5 was regarded high level. Mean of each internal consistent item and total mean for new recorded variable was computed. Participation in management of physical and material resources comprised of budget preparation; advising on the specific departmental needs; procurement and accounting. Summation score of the five Likerts scale items for each and every respondent was computed in order to make comparisons on the teachers and principal views. A t-test was used to establish whether there was a statistical significant difference between the means on the opinion of the teachers and the school principals. Simple regression analysis was run to determine the effect of the teachers' levels of participation in management of physical materials on teachers' motivation.

\section{Research Findings and discussion \\ Distribution of principals and teachers by gender}

The study revealed that majority $36(64.3 \%)$ of the school principals in school management were aged between $41-50$ years and that $125(38.6 \%)$ subject teachers were less than 30 years. The results indicate that teachers who were not in school management were younger compared to school principals who were a bit older indicating that the older the respondents the higher chances of holding positions in school management.Gender of a principal may affect teachers' motivation because teachers of same gender may feel more satisfied working under the leadership of a preferred gender. For example female principals may influence the motivation of female teachers as a result of their successful leadership.

\section{Teachers' level of Participation in Management of Physical and material resources}

The study sought to determine teachers' level of participation in management of physical and material resources. The study was guided by the research question: What is the teachers' level of participation in management 
of physical? The means on the views on views of subject teachers and school principals were computed in order to make comparisons. The descriptive analysis of teachers' responses indicated that highest mean of $($ mean $=2.87)$ for school strategic plan to address emerging issues and $($ mean $=2.65)$ moderate participation in requisition and procurement of facilities and equipment. The total cumulative mean (2.53) teachers indicate moderate level. This means that teachers' level of participation in management of physical and material resources was moderate according to the views of teachers. Consequently, cumulative analysis of principals' response on teachers' participation in management of physical and material resources indicated moderate level (3.49). Despite the mean differences, they fall within the range of 2 to 3.5 which is considered to be moderate participation according to Bademo and Tefera (2016).

This is an indication that subject teachers and school principals' responses on indicated moderate level of teachers' participation in management of physical facilities and material resources. Even though the teachers and principals responses on the level of teachers' participation on management of physical material resources indicated that there is moderate participation, the collaborated results through the observation schedule shows that there is little participation. This was evidenced by the observation check list which indicated that teachers did not have inventory of equipment and supplies. This shows that teachers did not fully participate in decision making relating to inventory of equipment and supplies in the departments. Further, the observation guide shows that teachers did not have records on maintenance and servicing of the facilities; classrooms, laboratories and library and revised framework on emerging issues. This shows that most of the teachers did not participate in maintenance and servicing of the facilities; classrooms, laboratories and library and revised framework on emerging issues an indication that most of the schools do not adhere to regulations that they must have such documents to promote transparency in schools. Generally, the observation guide confirms that teachers participated in management of physical facilities and there were documents to support such activities.

\section{T-test on the difference between the means of principals and teachers views on teachers' participation}

In order to establish whether there is a statistical mean difference between the teachers and school principals' opinion on the level of teachers' participation on management of physical material resources, a t-test was computed. The results is presented in Table 1 
Table 1: Independent Sample t- Test on teachers and principals views on teachers' participation in management of physical and material resources

\begin{tabular}{crlll}
$\begin{array}{c}\text { Levene's Test for } \\
\text { Equality of } \\
\text { Variances }\end{array}$ & t-test for Equality of Means \\
\hline F & Sig. & T & Df & $\begin{array}{r}\text { Sig. (2- } \\
\text { tailed) }\end{array}$
\end{tabular}

\begin{tabular}{ccccccc}
$\begin{array}{c}\text { Physical } \\
\text { Facilities }\end{array}$ & $\begin{array}{c}\text { Equal variances } \\
\text { assumed } \\
\text { Equal variances } \\
\text { not assumed }\end{array}$ & 5.624 & .018 & -6.073 & 377 & .000 \\
& & & -6.912 & 82.833 & .000 \\
\hline
\end{tabular}

The independent sample t-test results show that there was a significant difference between the teachers and school principals' opinion. $(\mathrm{M}=2.53$, $\mathrm{SD}=1.13)$ and principals $(\mathrm{M}=3.49, \mathrm{SD}=0.94)$ conditions; $\mathrm{t}(377)=-6.073, \mathrm{p}=$ 0.00 . This indicates that mean difference between the responses from the school principals and the teachers on the level of teachers 'participation in the management of physical and material was statistically significance.

\section{Regression analysis on the effect of the teachers' level of participation on motivation}

In order to establish the effect of teachers' participation in the management of physical and material resources on motivation, a regression test was conducted. This generated a model summary Table and ANOVA results as presented below.

Table 2: Simple regression model summary

\begin{tabular}{clccc}
\hline Model & $\mathbf{R}$ & $\mathbf{R}$ Square & $\begin{array}{c}\text { Adjusted } \mathbf{R} \\
\text { Square }\end{array}$ & $\begin{array}{c}\text { Std. Error of the } \\
\text { Estimate }\end{array}$ \\
\hline $\mathbf{1}$ & $.429^{\mathrm{a}}$ & 0.184 & 0.181 & 0.985741388 \\
\hline \multicolumn{5}{c}{ a. Predictors: (Constant), physical facilities } \\
\end{tabular}

As presented in Table 2 it can be deduced that 18 per cent of the total variability in the motivation is explained by teachers' participation in the management of school physical facilities. The results show that the adjusted $\mathrm{r}^{2}$ is 0.18 , which implies that teacher's participation in management of physical and material resources accounts for $18 \%$ of the variance in teachers' motivation. The value of adjusted $\mathrm{r}^{2}$ which is 0.18 implies that the that teacher's participation in management of physical facilities predicts teachers' motivation.

The Analysis of Variance (ANOVA) table was also generated with the aim of establishing whether teachers' participation in the management of physical and material explains the variation in teachers' motivation. The ANOVA results were presented in Table 3 
Table 3: ANOVA results on effect of teachers' participation in the management of physical and material resources on motivation

\begin{tabular}{ccccccc}
\hline & Model & $\begin{array}{c}\text { Sum of } \\
\text { Squares }\end{array}$ & Df & $\begin{array}{c}\text { Mean } \\
\text { Square }\end{array}$ & F & Sig. \\
\hline \multirow{2}{*}{1} & Regression & 55.824 & 1 & 55.824 & 57.45 & $.000^{\mathrm{b}}$ \\
& Residual & 246.808 & 254 & 0.972 & & \\
& Total & 302.632 & 255 & & & \\
\hline
\end{tabular}

a. Dependent Variable: motivation

b. Predictors: (Constant), physical facilities

Table 3 shows that teachers' participation in the management of physical and material resources had high explanatory power on variation in teachers' motivation. This is as attested F Statistics which has value F $(1,234)$ $=57.45, \mathrm{p}<.001$ suggesting that the model has high explanatory power hence acceptable for the regression equation

To establish the effect of teachers' participation in the management of physical and material resources on motivation, a simple regression test was run. This appears in Table 4

Table 4: Regression on teachers' participation in management of physical and material resources on motivation

\begin{tabular}{ccccccc}
\hline Model & \multicolumn{2}{c}{$\begin{array}{c}\text { Unstandardized } \\
\text { Coefficients }\end{array}$} & $\begin{array}{c}\text { Standardized } \\
\text { Coefficients }\end{array}$ & & T & Sig. \\
\cline { 2 - 4 } & B & Std. & Beta & & \\
& & Error & & & \\
(Constant) & 2.288 & 0.159 & & 14.42 & 0.000 \\
Physical & 0.399 & 0.053 & 0.429 & 7.58 & 0.000 \\
facilities & & & & & \\
\hline
\end{tabular}

a. Dependent Variable: motivation

Table 4 shows that teachers' participation in the management of physical facilities has effect on teachers' motivation. This is as shown by ( $p$ value $<0.001)$. The results also show that the coefficient of teachers' motivation is positive (2.28) which implies that, the slope "a" is statistically significant. The intercept of the regression line is $\mathrm{Y}=0.39 \mathrm{X}+2.29$, meaning that when teachers participation in management of physical and material resources increases by 1 unit teachers motivation increases by $22 \%$.

The regression equation is expressed as follows:

$\mathrm{Y}=\mathrm{a}+\mathrm{bX}$,

Whereby $\mathrm{Y}$ is teachers motivation, $\mathrm{X}$ is teachers' level of participation in management of physical material and physical resources and " $b$ " is the slope (gradient) of the line (the amount $\mathrm{Y}$ increases for each unit increase in $\mathrm{X}$ ) while "a" is the intercept. This generally implies that the more the teachers are involved in the management of physical and material resources the more they are motivated. 
The regression results of this study indicate that there is a significant relationship between teachers' participation in management of physical resources and teachers motivation as evidenced by $\mathrm{P}$-value $<0.005$. The findings concur with the Ali, Naeimeh, Javad, Hatam (2015); Lewin (2008) who established that teachers' level of participated in management of water, hygiene, and sanitation, procurement of equipment, learning materials was an important aspect of management. He added that teachers' participation in budget preparation, repairs and maintenances of classrooms, laboratories, toilets had effects on teachers' motivation. Similarly, Jasper, Le, Bartram (2012) revealed higher rates of absenteeism from schools during menses due to poor sanitation facilities. Teachers required an environment where they felt their needs were being met. The study is in line with the findings of Afshari, Bakar, Luan, Samah, and Fool (2009) who also found that teachers 'participation in ICT integration in educational programmes was a factor of motivation. Also the results concurs with the work of Matoke, Okibo, \& Nyamongo (2015) who established that participation in provision of physical and material resources had a significant statistical effect (p-value of .0126) on teacher motivation. Similarly, Chimombe (2011) reported that provision of physical facilities created an environment that promoted effective teaching and learning. Participation in management of facilities and resources is an important aspect due to the social and health influences in relation to motivation.

\section{Conclusion}

The study established that teachers were moderately involved in management of physical and material resources. There was a significant difference in between the principals' and teachers' views on teachers' participation in management of physical and material resources t (377) = $6.073, \mathrm{p}=0.00$. The study revealed a statistical significant relationship between teachers' level of participation in the management of physical facilities and their motivation $(\beta=.399, p$-value $<.01)$. Therefore, the null hypothesis "there is no relationship between teachers' level of participation in the management of physical facilities and material resources on teachers' motivation" was rejected. This means that teachers' participation in management of physical and material resources has significant effect on teachers' motivation. There is need to embrace participative structures that encourage teachers' participation in management of physical facilities and material resources. Through such ventures the teachers will highly be motivated to work and consequently improving the quality of education in Kenya. 


\section{Recommendations}

Institutions should put in place mechanisms where teachers are involved in management of school physical facilities and material resources. Such facilities cater for teaching-learning, social and health purposes and therefore teachers should be at the forefront in various aspects of management in educational institution. This could enhance their motivation leading to effectiveness in performance of duties.

\section{References:}

1. Afshari, M., Bakar, K. A., Luan, W. S., Samah, B. A., \& Fooi, F. S. (2009). Factors affecting teachers' use of information and communication technology. Online Submission, 2(1), 77-104.

2. Akinfolarin, C.A. (2015). Organizational climate and physical resource utilization in vocational and technical education in colleges of education in South West Nigeria. International Journal of Educational Policy Research and Review Vol.2 (1), pp. $\quad$ 8-16 Available online at http://www.journalissues.org/IJEPRR/.

3. Ali, A. H., Naeimeh, K., J. K, \& Hatam. (2015). A Study on the Relationship between Schools' Health and Teachers' rganizational Commitment. International Journal of School Health 2:4.

4. Ayele, D. (2014). Teachers' job satisfaction and commitment in general secondary schools of Hadiya Zone, in southern nation nationality and people of regional state. Thesis. Jimma: Jimma University.

5. Ayeni, A. J. \& Afolabi, E. R. I. (2012). Teachers' instructional task performance and quality assurance of students' learning outcomes in Nigerian secondary schools. International Journal of Research Studies in Educational Technology, 1 (1), 33-34.

6. Bush, T,. Joubert. R. , Kiggundu, E., \& Rooyen, J.V. (2010). Managing teaching and learning in South African schools. International Journal of Educational Development 30(2), 16.

7. Chimombe, T. R. (2011). An analysis of biodiversity on fallow land in Chivi district, Zimbabwe. BSc thesis, Department of soil science and agricultural engineering, University of Zimbabwe.

8. Dawson, P. (1994). Organizational Change: A Processual Approach London: Paul Chapman.

9. Dent, E.C., \& Galloway S. G (1999). Challenging "Resistance to Change." The Journal of Applied Behavioral Science, 35; 25.

10. Devos, G., Tuytens, M., \& Hulpia, H. (2014). "Teachers' Organizational Commitment: Examining the Mediating Effects of Distributed Leadership," American Journal of Education 120, no. 2: 205-231. 
11. Duran, N.V. (2008). School building condition, school attendance, and academic achievement in New York City public schools: A mediation model. Journal of Environmental psychology 28(3), 278-286.

12. Earthman, G.I. (2004). "Prioritization of 31 Criteria for School Building Adequacy”, American Civil Liberties Union Foundation of Maryland.

13. Eliasu, I., Abdul, R.A., \& Jatuat, W. (2016). State of academic facilities and its influence on teachers' job stress in Tamale polytechnic. African Journal of Business Management.Vol. 10(2), pp. 24-31, 28.

14. Freeman M.C., Greene L.E., Dreibelbis R., Saboori S., Muga R., Brumback B., \& Rheingans R. (2011). Assessing the impact of a school-based water treatment, hygiene and sanitation me on pupil absence in Nyanza province, Kenya: A cluster-randomized trial. Trop. Med. Int. Health. Vol 17:380-391.

15. Garipagaoglu, C.B. (2013). Examining organizational commitment of private school teachers. Journal of educational and instructional studies in the world. Volume: 3 Issue: 2 Article: 04 ISSN: 2146-7463.

16. Gouri, K. B., Pravat, K. S., \& Soumen, D, (2012). Assessment of School Infrastructure at Primary and Upper Primary Level: A Geospatial Analysis. Journal of Geographic Information System, Volume 4, 412-424.

17. Ireri, C. M. (2015). Influence of Motivation on Employee Performance in Non - governmental Institutions: A Case of Kenya Tenri Society in Embu County. Unpublished Research Project Report, University of Nairobi.

18. Isaiah, M. N. (2013). Linking the school facilities conditions to teachers' level of job dissatisfaction in the South Central Region of Botswana. Int. Rev. Soc. Sci. Hum. 4(2):196-205.

19. Jasper, C., Le T.T., \& Bartram, J. (2012). Water and sanitation in schools: a systematic review of the health and educational outcomes. Int J Environ Res Public Health. 2012; 9:2772-2787.

20. Juma, F. (2011). The relationship between mode of Teacher Motivation and Students Academic Performance in public secondary schools in Bungoma North District. Moi University Unpublished M.E.D Project.

21. Kanter, R. M., Stein, B. A. and Jick, T. D. (1992). The Challenge of Organizational Change. New York: The Free Press.

22. Kimutai,T., and Kosgei,Z., Kimtai,K.V (2012). The Impact of head teachers Supervision of teachers on student's academic performance. Journal of Emerging Trends in Educational Research and Policy Studies, vol 3 issue 3. 
23. King'oina, O. J., Kadenyi, M.M., \& N. Ngaruiya, N.B. (2015). Effect of Teachers' Morale on Standard Eight Pupils' Academic Achievement in Public Primary Schools in Marani Sub-County, Kenya. International Journal of Scientific and Research Publications, Volume 5, Issue 10, October 20151 ISSN 2250-3153. www.ijsrp.org

24. Korkmaz, Y., İhsan, S., Yıldiz, O.U., Fikret, S. (2011). Examining the effect of recreational activities on universitystudents' self-esteem. Sport SPA Vol. 8, Issue 2: 15-19.

25. Leithwood, K., \& Jantzi, D. (2006). Transformational school leadership for large-scale School Effectiveness and Improvement, Vol 17(2), 201-227.

26. Lewin, M.K. (2008). Strategies for Sustainable Financing of Secondary Education in Sub-Saharan Africa. Washington D.C: World Bank Report.

27. Matoke, Y.K., Okibo, W.B., \& Nyamongo, D.N. (2015). Determinants of teacher motivation in public secondary schools in Masaba South Sub-County, Kenya. International Journal of Economics, Commerce and Management, 3(6), 139-160.

28. Momanyi, N.V. (2015). Factors Affecting Teacher Motivation in Public Secondary Schools in Marani Sub County, Kisii County. Unpublished Research Project. University of Nairobi.

29. Olatunji, A.A. (2013). Post-occupancy evaluation of Lagos State Polytechnic Facilities: A User-Based System. Journal of Emerging Trends in Engineering and Applied Science (JETEAS). 4(2):229-236.

30. Pettigrew, A. M. and Whip, R. (1993). Managing Change for Competitive Success Cambridge: Blackwell.

31. Republic of Kenya. (2012). Basic Education Act. Nairobi: Government printer.

32. Salifu, I. (2014). Barriers to teacher motivation for professional practice in the Ghana education service. Policy Futures in Education, 12(5), 718-729.

33. Stephen, C.,Todd, B., Kenneth, G. B. (2015).Unfreezing change as three steps: Rethinking Kurt Lewin's legacy for change management. Human relations Sage, Vol. 69(1) 33- 60.

34. Tan,T.H., \& Waheed, A. (2011). Herzberg's Motivation-Hygiene Theory and Job Satisfaction in the Malaysian Retail Sector: The Mediating effect of love of Money. Asian Academy of Management Journal, Vol. 16, No. 1 pp. 73-94.

35. Vanbaren, J. (2010). The Definition for work motivation. [Online] Available: httpVelez, S. (2007) what is Motivation? Ezine articles.http://ezinearticles.com/?What-Is- Motivation\&id=945902 
36. Wadesango, N. (2012). The Influence of Teacher Participation in Decision-making on their Occupational Morale. Journal of Social Science, 31(3): 361-369 (2012).

37. Wedam. E., Asante. J., \& Debrah, I. A. (2014). Can Girls Attend and Complete School in Ghana; Measuring Parents Educational Status as a Factor of Confidence and Belief in Girls Education. Science and Education Publishing. American Journal of Educational Research, Vol. 2, No. 7, 493-502.

38. Wilson, D. C. (1992). A Strategy of Change. London: Routledge. 